\title{
Informal and Private: Veto Threats Over the Freedom of Information Act
}

Kevin M. Baron

Austin Peay State University

ABSTRACT: The Constitution grants the president a formal role in the law-making process through the veto power. Neustadt taught us that presidential power is the power to persuade that the president can employ to bargain during the legislative development process. Building from Azari and Smith's (2012) work, this research demonstrates how the veto bargaining functions as an informal institution operating within the formal rules and constraints of the legislative development process, as there are no formal rules to govern presidential bargaining with Congress. The president's power to persuade becomes contextual and situational to the issue, individual, and moment in time. The Freedom of Information Act (FOIA) is employed as a case to examine a policy issue that presidents do not want, as it serves as a congressional check on executive power. By examining the development of FOIA and the first amendment to the bill, we can examine how and why presidents will choose to employ a private versus public bargaining strategy based on the context in which they find themselves. Using the same policy issue across three administrations - Lyndon Johnson, Richard Nixon, and Gerald Ford - provides consistency in examining the political contexts on an issue each president wanted to avoid but was forced to engage with by Congress. Understanding veto threats as an informal institution provides the context to understand why presidents may choose to "go private" instead of public as a strategy. In this way, a benefit exists for presidents to seek to persuade and influence policy outcomes outside of the public eye. Original archival research was conducted to provide the context-rich examination of the internal White House conversations along with the conversations between the president and Congress.

Key words: FOIA, veto, presidency, congress, policymaking, informal institutions

This is a draft of a working paper prepared for the American Political Science Association (APSA) Annual Meeting in San Francisco, now virtual, in September 2020. Questions and comments are always welcome at baronkm@apsu.edu 
On August 12, 1958, President Dwight Eisenhower signed H.R. 2767, "To amend Section 161 of the

Revised Statutes with respect to the authority of federal officers and agencies to withhold information and limit the availability of records." ${ }^{1}$ The bill itself consisted solely of one line of text that would amend the Housekeeping Statute of 1789 in order to prevent the president from using that law to deny information and records to Congress. The line merely stated, "This section does not authorize withholding information from the public or limiting the availability of records to the public." ${ }^{2}$ After signing the bill, Eisenhower issued a brief signing statement, reasserting his position on matters pertaining to control over information. The statement said, in part,

In its consideration of this legislation the Congress has recognized that the decisionmaking and investigative processes must be protected. It is also clear from the legislative history of the bill that it is not intended to, and indeed could not, alter the existing power of the head of an Executive department to keep appropriate information or papers confidential in the public interest. This power in the Executive Branch is inherent under the Constitution. ${ }^{3}$

The language and tone of the statement reflected the strong position Eisenhower had taken upon immediately coming into office when it came to control over public information. While Eisenhower's early adoption and creation of executive privilege has been well documented, it is important to understand not just the context of this moment, but how it shaped future policy debates between the president and Congress over what would become the Freedom of Information Act (FOIA) and access to executive branch information (Rozell 2010; Baron 2019).

The Housekeeping Statute Amendment was a congressional response to Eisenhower's increased claims of an inherent constitutional "privilege" that existed within the executive branch to withhold

\footnotetext{
${ }^{1}$ Dwight D. Eisenhower, Statement by the President Upon Signing Bill Relating to the Authority of Federal Agencies To Withhold Information and Records. Online by Gerhard Peters and John T. Woolley, The American Presidency Project https://www.presidency.ucsb.edu/node/233846

2 "Freedom of Information Act and Amendments of 1974 (P.L. 93-502)." Joint Committee Report, House Committee on Government Operations and Senate Committee on the Judiciary. Government Printing Office, Washington, DC, March 1975.

${ }^{3}$ Dwight D. Eisenhower, Statement by the President Upon Signing Bill Relating to the Authority of Federal Agencies To Withhold Information and Records.
} 
information or testimony from Congress and the public. Once in office, Eisenhower began to systematically centralize control over information within the executive office of the president. He created the Office of Strategic Information (OSI) within the commerce department in 1954, leading to a three-year fight with Congress, who ultimately refused to appropriate a budget for OSI, effectively shutting it down in 1957. ${ }^{4}$ The Housekeeping Statute Amendment arose as a congressional response executive actions that began with the creation of the Special Subcommittee on Government Information under the House Government Operations Committee in $1955 .{ }^{5}$ The subcommittee was chaired by Representative John Moss (D-CA) a sophomore House member from Sacramento, CA. Moss was and would continue to be persistent in his determination for oversight and access to executive information throughout his congressional career. The creation of the Moss Subcommittee institutionalized the issue of freedom of information, meaning public and congressional access to executive branch information. While the issue and the Moss Subcommittee were still in their infancy during the policy fight with Eisenhower, the episode and actions taken at both ends of Pennsylvania Avenue would set-up a longterm power struggle between branches that continues to this day. The precedent set by Eisenhower would inform his successors through multiple rounds of policy development on this issue.

Veto power provides the president with a powerful tool when it comes to influencing policy with Congress, marking the formal power of the president's role in lawmaking. However, as the Constitution nor statute provide any specific structure outside of granting presidential veto power coupled with Congress's power to override, scholarship has often focused on the informal process of presidential

\footnotetext{
${ }^{4}$ Staff Memorandum, August 2, 1965. Folder: Staff Memos [1963-1965] Box No. M-21, Center for Legislative Archives, National Archives, Washington, DC; Statement from Congressman John E. Moss, March 30, 1965. Folder: Freedom of Information Miscellaneous [1965-1966] Box No. M-25, Center for Legislative Archives, National Archives, Washington, DC. For a more complete discussion on OSI, see Baron 2019.

${ }^{5}$ Letter from William L. Dawson to John Moss establishing the Special Subcommittee on Government Information, in Preface of Subcommittee Hearing Opening Statement, 1955. Folder: Hearings (1955-1956) - Correspondence re: plans and preparation [October 1955-February 1956], Box No. M-5, Center for Legislative Archives, National Archives, Washington, DC.
} 
influence with Congress and coalition building to determine outcomes. Neustadt (1991) taught us the power of the presidency to persuade through bargaining as a means of advantaging the president, while Edwards (1990) found that presidential influence was marginal at best. Twenty-five years ago, McCarty and Poole (1995) recognized the formal power contained in the Constitutional executive veto as an institution, but questions how much presidential influence had expanded through informal influence. There is no question that veto power grants the president influence with Congress in lawmaking, as scholarship on veto bargaining and veto threats focuses heavily on formal theory and predictive models to demonstrate rational behavior in order to develop generalizable explanations applicable across time (Lewallen 2017; Cameron and McCarty 2004; Conley and Kreppel 2001; Cameron 2000). This research provides insight and support for causal mechanisms that can measure influence, a difficult concept in and of itself, as well as what outcomes presidential influence has provided, whether that is in policy agenda setting or policy outcomes. What this scholarship does not account for is the context missed by aggregate data or formal models. The context, in this case, can be elaborated by using the concept of informal institutions as established by Azari and Smith (2012) to place the informal actions and decision making of the president on issues of policy, and when and in what ways to employ the use of veto threats.

The ability of informal institutions to operate simultaneously with formal institutions within an established democracy opens a door to examine veto threats in a new way. Azari and Smith recognize and define institutions as having both formal and informal characteristics that structure and influence behavior. They identify informal institutions with Helmke and Levitsky (2004) as being unwritten, socially shared rules that can enforced outside official channels. As Azari and Smith state, "informal institutions exist when shared expectations outside the official rules of the game structure political behavior" (Azari and Smith 2012, 39). We can then distinguish and separate behavior from the formal institutional rules to identify and examine this informal institution at work. Azari and Smith develop three functions of 
informal institutions within American democracy as a completing mechanism, or one to fill gaps in existing formal rules or solve ambiguities in formal institutions; as a parallel function that regulates behavior jointly with formal rules; and as a coordinating mechanism to integrate the operation of multiple intersecting institutions. While Azari and Smith provide cases demonstrating each informal institutional function, they use the public presidency as a case that uses all three functions. The ideas of the public presidency, and of going public as provided by Kernell (2007) is often applied to the use of presidential veto threats, as the president will seek to sway public opinion as a way to favorably influence Congress. When it comes to lawmaking, going public is not always a viable strategy for presidents as Conley (2003) discovered that George H.W. Bush found more success in going private working directly with Congress behind the scenes out of the public spotlight. Kelley and Marshall (2009) find that veto bargaining power is increased when coupled with the use of signing statements as unilateral power increases the presidents influence with Congress as they demonstrate with George W. Bush. The lack of a formal process to structure presidential decision making on policy constructs an informal institution where the president will behave as a response based on the context of the political moment they are in.

The process of the presidential role in lawmaking is one established by a formal rule in the Constitution, but can best be understood as an informal institution that serves all three functions as established by Azari and Smith. As a completing function, the presidential role can be examined in detail through the informal behavior demonstrated during any stage in the policymaking process. While the role of Congress in lawmaking is defined by formal institutional rules and procedures, the role of the president has no such formal structure to govern behavior, so informal institutions, such as veto threats, statements of administration policy (SAPs), signing statements, as well as the strategies of going public or going private have been created to fill those gaps. As a parallel function, presidential behavior in lawmaking is structured simultaneously with the use of the veto. Veto power grants the president 
formal power within the process but how the president decides to deploy this tool, when, and in what ways is structured as an informal institution. As a coordinating function, presidential behavior is reconciled through examination of actions taken during the legislative development process in order to clarify the presidential role. The above example demonstrates how Eisenhower was less interested in the policy developed by not bargaining directly with Congress, but rather relying on claims of inherent power to disregard the policy as needed. ${ }^{6}$ While Eisenhower could have vetoed the bill, he signed it and chose to issue a signing statement upholding his informal authority to keep information from Congress or the public as determined to be in the public interest for national security. The completing function is shown through the choices made by Eisenhower in not seeking engagement with Moss and Congress, and to sign the bill. His choices and actions can be understood as an informal institution. The parallel function is evidenced in Eisenhower's decision to not employ the veto, but rather to reiterate control of the implementation process that runs parallel to Congress's legislating authority. Control over implementation informed Eisenhower's behavior and influenced his decision making, in knowing that the reach of Congress's authority on this policy was limited as he retained inherent power to control the flow of information. The coordinating function provides the ability to analyze the role of the formal veto power with the informal power the president exerts in seeking to influence policy outcomes, including how veto threats are employed and during which stages of the process.

While the president comes into office with their own legislative agenda and priorities, they must balance those interests with the ongoing legislative agenda from Congress (Jones 1994). This establishes an inherent tension between the president and Congress during legislative negotiations and bargaining that is structured by the formal institutional rules, but operates through informal norms (Goren 2013;

\footnotetext{
${ }^{6}$ As of this draft, archival research at the Eisenhower library has yet to be conducted due to circumstances created by the conronavirus. The information and conclusions here are based on information taken from the digital archives at the Eisenhower Library as well as from archival research conducted at the National Archives. It is necessary to note that the Eisenhower case is incomplete as I currently lack details and evidence to show his role in the process leading to the passage of the Housekeeping Statute Amendment.
} 
Skowronek 2011). The veto power combined with the informal institutions would seem to favor the president under these conditions by providing a strong bargaining position from which to negotiate with Congress. However, as Goren found with the Base Realignment and Closing Commission (BRAC) process, Congress can at times alter the playing field to provide them rival power when negotiating with the White House. While the BRAC example from Goren shows how Congress can create a formal structure establishing the ground rules for negotiation on a contentious issue that places the president onto equal footing with Congress. The BRAC process demonstrates the tension formed through informal negotiations that exist even within a formal structure. When examining the issue of access to information, the situation is not that different. As the Eisenhower example demonstrates, Congress responded to increasing episodes of executive privilege and denial of information by creating the Moss Subcommittee, thereby institutionalizing the issue within Congress and providing the formal structure and legitimacy for Congress to pursue action against the executive branch. The tension created by this structure provides us the ability to examine the context of this situation through using the informal institutions framework to understand presidential decision making over a contentious policy issue. Presidents do not seek to influence all policy being developed in Congress, but those to which they believe will pass and will have an important impact. President's then will seek to engage Congress on legislative development when it suits their needs. We would expect presidents to seek influence on policy items on their own agenda, but also likewise on policy items they may oppose that are on congresses agenda. Using FOIA as a case provides an opportunity to contextualize presidential decisionmaking strategy based on the politics of the moment they find themselves within on a policy issue they do not want. Scholars tend to focus research on whether presidents are successful or not on getting their policy agenda through Congress, but equally important is examining how presidents deal with policy they are opposed to. A contextual analysis of this situation, like with FOIA, offers a chance to look at the political factors under consideration for decision making, such as partisan makeup of Congress, 
public opinion or approval ratings, scandals or exogenous events, the ongoing policy agenda, and presidential control over the implementation outcomes. By delving deep into a contextual analysis, we are able to process trace and sequence, connecting the relevant factors leading to a strategy developed by the president in determining how they choose to engage with Congress, whether they seek a private bargaining strategy or decided to go public. This type of analysis can show how presidential decisionmaking is fluid and not based on any set of pre-existing structures, but rather engaged in an informal process than can and does change based on the issue and the context of the moment.

For this paper I am delving into three presidencies to examine how the informal institution of bargaining on policy informed the decision-making on when and in what ways the president engaged with Congress on FOIA. In particular is the president's decision to use veto threats in either a private or public manner. This research will examine the original passage of FOIA under Lyndon B. Johnson in 1966, and the passage of the first amendments to FOIA in 1974. The bargaining over what would become the 1974 FOIA amendments began under Nixon and continued with Ford after Nixon's resignation. Using a single policy issue across multiple presidencies provides consistency in the content of the policy. FOIA provides a policy where each president was adamantly opposed to the policy, yet each behaved in a different manner, yet led to the same outcome of Congress getting what it wanted over the objections of the president. Additionally, the FOIA case offers rich context in examining how Congress can utilize the institutional structure of committees, hearings, and investigations as a tool to strengthen their bargaining position vis-à-vis the president on policy (Baron 2019; Kriner and Schickler 2016). As an issue, freedom of information or access to government records places each president in a conundrum, whereby they want to publicly support transparency as a value of democratic health, but they also want to control the flow of information from the executive branch to Congress or the public. In the period under examination here, Congress was able to successfully use this conundrum against the president and were not only able to get FOIA passed and signed by LBJ, but also passed the first amendments in 
1974 by overriding Ford's veto. The complex political picture that emerges from the case study is one where we can see the factors that influenced actions through the informal institution of policymaking between the legislative and executive branches. The FOIA case provides the context to see why both Johnson and Nixon preferred to bargain privately with Congress, though for very different reasons, and why Ford first opted for a private approach but then believed going public would help him stop Congress from overriding his veto.

The purpose of this research is twofold. The first is to broaden our perspective in understanding veto threats and veto bargaining through the framework of informal institutions. This perspective will add to the existing literature by providing a new lens to understand the fluidity of executive legislative bargaining over policy in order to account for the dynamic nature of presidencies that change from administration to administration while also accounting for the partisan structure of Congress. The informal institutions lens connects to the second by creating new avenues in theory development through the use of process tracing and sequencing to construct a timeline of events and the confluence of relevant factors that influenced the politics, both in the current moment and in future moments. As you will see, the actions taken by Eisenhower in the opening example influenced the decision making of LBJ, just as the actions taken by LBJ with Congress would influence the decisions and actions of Nixon and Ford on the FOIA amendments. Delving deep into a contextual analysis highlights and raises the potential for new research questions and theory development that adds to our collective knowledge. Finally, the historical examination provided through the case study provides the opportunity to draw connections from the past the to the present. Understanding situations where Congress can vest the president in veto bargaining over an issue that constrains executive power can help us to examine similar situations in the present moment. Congress continues to struggle with access to executive branch information, becoming even more pronounced with the Trump administration. Examining history can be instructive to understanding presidential and congressional decision making, including what 
factors matter in any given political moment. The context of the past can help illuminate our contemporary politics.

\section{LBJ's Strategic Surrender on FOIA}

As described in the Eisenhower example, the political battles between Congress and the White House had been going on while LBJ was in the Senate and then the White House as vice president. The context of the moment LBJ found himself in after being sworn in as president was quite different than when he supported the Housekeeping Statute amendment, ushering it through the Senate as Majority Leader in 1958. But it was not just the context that different for LBJ, it was also his position. He was no longer a legislator, he was president, and the perspective on some issues can change dramatically depending on which end of Pennsylvania Avenue you find yourself. Freedom of information, government secrecy, public access to records, executive privilege had combined into an issue that percolated on Capitol Hill but was not on the president's agenda. As history shows, LBJ was focused on transforming President John F. Kennedy's New Frontier into his own Great Society agenda, determined to use the moment to push for massive legislative, social and racial reforms. It would seem that for Johnson, freedom of information had been a great issue to attack Eisenhower with, but it no longer belonged as part of the Democratic Great Society plans.

The shifting context was not just impacting the president and the executive branch, it had infected Congress as well. The partisan politics between Eisenhower and the Democratically controlled Congress had paved the way for Moss to use his subcommittee as a cudgel to hammer the president on executive privilege and excessive government secrecy, a role Moss was quite successful with. The 1960 election changed the politics, especially as Moss had been appointed as head of the Democratic 
Speakers Bureau where he actively campaigned for and worked directly with Kennedy. ${ }^{7}$ Moss's profile within Congress had also raised as he was appointed as deputy whip in 1960 and continued to use his subcommittee chair to provide campaign assistance for other members on the issue of government secrecy. ${ }^{8}$ Once Kennedy was elected however, Democratic congressional leadership told Moss to stand down on this issue, as they did not want to be seen attacking the new president. However, the success found by the Democrats in using freedom of information against Eisenhower became the playbook that congressional Republicans adopted against Kennedy and Johnson. Even though Republicans remained in the minority during both the Kennedy and Johnson administrations, their strategy on using executive privilege and freedom of information against the presidents, while accusing congressional Democrats of going easy on them, provided an opportunity for Moss and Senator Edward Long (D-MO), Moss's counterpart in the Senate, to coalition build and grow bipartisan support on a public records bill. ${ }^{9}$ During the $87^{\text {th }}$ Congress, $1961-1963$, seven different bills were introduced in the House and Senate focused on the freedom of information issue and access to government records. ${ }^{10}$ Early into the $88^{\text {th }}$ Congress, 1963-1965, the Senate introduced two bills, one of which would pass the Senate with unanimous consent in 1964, but no action would be taken in the House on that bill. ${ }^{11}$ The $88^{\text {th }}$ Congress

\footnotetext{
7 Letter exchange between John Moss and Myer Feldman, Oct. 28 - Nov. 1, 1960. Folder: Moss - Speakers Bureau [1960 - 1961], Box No. M-7, Center for Legislative Archives, National Archives, Washington DC.

8 Press Release, DNC Publicity Division, Oct. 6, 1960. Folder: Moss - Speakers Bureau [1960 - 1961], Box No. M-7, Center for Legislative Archives, National Archives, Washington DC.; Letter to Senator Estes Kefauver from Jack Howard, Sept. 27, 1960. Folder: Moss - Speakers Bureau [1960 - 1961], Box No. M-7, Center for Legislative Archives, National Archives, Washington DC.

9 Letter from Sam Archibald to Paul Fisher, Feb. 28, 1963. Folder: Freedom of Information Center (University of Missouri) [1958 - 1963], Box No. M-15, Center for Legislative Archives, National Archives, Washington DC. ${ }^{10}$ The bills introduced were: S. 1887 ( $87^{\text {th }}$ Congress) introduced by Senator Ervin; S. 1567 ( $87^{\text {th }}$ Congress) introduced by Senators Hart, Long, Proxmire; S. 1907 ( $87^{\text {th }}$ Congress) introduced by Senator Proxmire; S. 3410 ( $87^{\text {th }}$ Congress) introduced by Senators Dirksen, Carroll; in the House: H.R. 9926 ( $87^{\text {th }}$ Congress) introduced by Representative Walter; and Moss reintroduced his freedom of information bill that had been introduced in the previous Congress (no bill number available currently). US Senate, Committee on the Judiciary, Subcommittee on Administrative Practice and Procedure. 1974. Freedom of Information Act Sourcebook. 93 ${ }^{\text {rd }}$ Congress, $2^{\text {nd }}$ Session. Washington: US Government Printing Office.

${ }_{11}$ The first bill was S. 1663, introduced by Senators Dirksen and Long; and the second, S. 1666 was introduced by Senator Long with 21 cosponsors. US Senate, Committee on the Judiciary, Subcommittee on Administrative
} 
would see the assassination of Kennedy and Johnson's ascension to president, followed by his election victory in the 1964 election. The shift into the Great Society agenda led LBJ to focus on coalition building in Congress, in particularly on issues surrounding civil and voting rights, and while he was focused on those items, Moss and his allies in Congress kept pushing forward on development of the bill that would become FOIA. ${ }^{12}$ At the start of the $89^{\text {th }}$ Congress, $1965-1967$, Moss and Long jointly introduced bills, S.1160 and H.R. 5012, targeting open government records. ${ }^{13}$ At this point, the Johnson administration began to take an active interest in stopping the freedom of information bills before they could pass, and were focused on Moss and House, rather than Long and the Senate. We can already begin to see the informal institutions at work through the completing function, the administration begins to engage in the lawmaking process reserved for Congress in order to influence outcomes. In this case, the president is wanting to stop the passage of a freedom of information bill before it can leave committee. A parallel function emerges as we can see Congress, both the House and Senate grapple with legislative development on a salient policy issue through formal rules and processes, yet the president and other administration officials now begin to coordinate behavior to disrupt the formal process at play in Congress. The coordinating function is just beginning at this point within the Johnson administration, but as we will see, multiple administration officials from across various agencies and White House advisors begin to coordinate efforts with the President in making a case for the defeat of any public records bill as an unconstitutional usurpation of executive power. These coordinating actions then move from the executive to the legislative branch, as administration officials and LBJ seek to convince party

Practice and Procedure. 1974. Freedom of Information Act Sourcebook. $93^{\text {rd }}$ Congress, $2^{\text {nd }}$ Session. Washington: US Government Printing Office

12 I must note here that the press played a large role as advocacy group for the freedom of information issue and in helping get FOIA passed. There are interesting dynamics to press as advocate, especially when many newspapers and media organizations endorsed the legislation. Moss hired multiple journalists to work on his subcommittee as staff and frequently brought in journalists as witnesses during hearings. I have purposefully left the press as advocacy organization out of this paper as that is not the focus here and could be its own paper. For more details on the press role with Congress in development of FOIA, see Baron 2019.

13 Press Release, 17 February 1965: Papers of Lyndon Baines Johnson, President 1963-1969, EX FE 3-2 Wreath Laying (11/22/63-9/18/65), Folder: FE 4-1 Presidential Powers, Box 6, LBJ Presidential Library. 
leadership in Congress to suspend efforts on the legislation using veto rhetoric in order to interrupt the lawmaking process (Hassell and Kernell 2015).

The message sent by Moss and Long at the start of the $89^{\text {th }}$ Congress to both congressional leadership and the administration was they were moving forward on a bill. In the House, Moss was bolstered in his coalition building by the confluence of two factors. The first being the election of freshman Republican from Illinois, Donald Rumsfeld, who specifically requested assignment to the Moss Subcommittee as he believed in the importance of the freedom of information issue (Foerstel 1999). Rumsfeld became a strong Republican ally for Moss, who then helped swing many in the House Republican caucus to support the efforts on the legislation, including House Minority Leader Gerald Ford. House Republican's saw the issue much as Democrats did when Eisenhower was president, an issue that resonated with the press and voters, and one they could use to discredit the Johnson Administration. Congressional Republican began running a "credibility gap" campaign against LBJ as they ramped up efforts for the 1966 midterms elections by arguing the antidemocratic secrecy and lack of transparency from the administration left the nation vulnerable. ${ }^{14}$ With the support from Rumsfeld and Ford, the coalition supporting Moss in the House grew bigger. The problem for Moss was his own party's leadership and the president.

At best, LBJ saw Moss and the efforts to pass a public records law as distraction, but many within the administration saw the potential law as undermining the power of the presidency. Moss had scheduled the first hearings on H.R. 5012 for late-March 1965, while simultaneously many cabinet secretaries and administration officials, following the lead of the Justice Department, made the argument to LBJ that the legislation was unconstitutional, interfering with all executive agencies, "ability

\footnotetext{
${ }^{14}$ The Ford Presidential Library archive contains documents on the Republican efforts to run a discrediting campaign against LBJ and congressional Democrats during the 1966 mid-term elections. With Rep. Donald Rumsfeld on the Moss Subcommittee pushing from the inside, House Minority Leader Ford was able to get a large group of Republican House members on board to support FOIA, which could be used as a partisan attack on LBJ. This was referred to as the "Credibility Gap" campaign for the 1966 midterms.
} 
to discharge their responsibilities effectively." 15 Phillip Hughes, assistant director for legislative reference at the Bureau of Budget (BOB) sent a memo to Lee White, special counsel to LBJ, discussing the upcoming hearings in the House, stating that $\mathrm{BOB}$ regards the bill as "threatening a serious legislative encroachment on executive power." ${ }^{16}$ Hughes continued in the memo to note the issue would be too sensitive to be handled in a hearing, recommending the issue warranted immediate attention and they must talk with House leadership to prevent the bill from moving forward to a floor vote. Memo's from the Office of Legal Counsel (OLC) and the DOJ supported Hughes position by arguing that the language of the bill would harm the public interest in ripping open executive branch records through a "selfexecuting word formula" while exempting Congress from the same public access. ${ }^{17}$ The same memos note that DOJ was already drafting language to change the bill to make it more palatable for the administration at the direction of Johnson's advisor and press secretary, Bill Moyers.

At the Moss subcommittee hearing, the administration's position on the bill was made clear as several DOJ officials testified that the legislation was unconstitutional and every executive agency objected. While the hearing was underway, Hughes sent a detailed letter to House Government Operations Chair, William Dawson, ripping apart the legislation as inadequately protecting the public interest, and reiterating that $\mathrm{BOB}$ opposed the bill. ${ }^{18}$ While Congress was holding hearings, the administration was actively working behind the scenes to stop the bill outright, although they were already preparing to bargain on changing the language. The signaling from the administration to Congress was centered on defeat, yet internally, administration officials were working on alternative

\footnotetext{
${ }_{15}$ Memo for the President from Wilfred Rommel, June 29, 1966. Folder: Executive Folder LE/FE 14-1, WHCF Box 44, LBJ Presidential Library.

${ }^{16}$ Memorandum for Mr. Lee White, 19 March 1965: Office Files of Harry McPherson, folder: Office Files of Harry McPherson Executive Privilege, Box 22, LBJ Presidential Library.

${ }_{17}$ Memo for Bill Moyers from Leon Ulman, March 16, 1966. Folder: Executive Folder LE/FE 14-1, WHCF Box 44, LBJ Presidential Library.

18 Letter to William L. Dawson, 30 March 1965: Office Files of Harry McPherson, folder: Office Files of Harry McPherson Executive Privilege, Box 22, LBJ Presidential Library.
} 
language to the bill. We can clearly see the coordinating functions at play as the administration had prepared a multi-tiered strategy based on the unknowns of bargaining with Congress. While administration officials were engaging in veto rhetoric, clear in their position on the bill but not yet invoking the veto specifically, they were preparing to move in different directions as needed. At this time, while the legislation was still in committee, it was easier for LBJ to focus on stopping the legislation from moving forward, so there was not yet the need to invoke a veto outright, as the bill had yet to receive any votes.

Shortly following the Moss Subcommittee hearing, House Democratic leadership was in their weekly meeting with LBJ, who demanded of Speaker John McCormack (D-MA), Majority Leader Carl Albert (D-OK), and Majority While Hale Boggs (D-LA) to explain why the Moss Subcommittee was moving forward on their government secrecy bill. The president commented that the legislation was terrible, asking, "What is Moss trying to do to me?" He continued, "I thought Moss was one of our boys, but the Justice Department tells me this goddamn bill will screw the Johnson Administration" (Lemov 2011). LBJ then told the House leaders that Moss needed to be "brought in line." Within an hour of this meeting, Moss found himself sitting in the Speakers office after being pulled out of his own subcommittee hearing listening to Speaker McCormack express the president's frustration and position. Moss was undeterred by this, as he was already aware of the president's and the entire administration's position on his bill, yet he had spent over a decade working on this issue at this point, and with the support from the coalition he had already built in the House and Senate, he was confident that he could come to some kind of agreement with LBJ to get his support.

Development continued into the summer when by August, Sam Archibald, the Moss Subcommittee Chief of Staff, sent an updated version of the bill to Lee White, advisor to the president, 
asking for comments, and noting that input from White would be helpful. ${ }^{19}$ White forwarded the bill and Archibald's letter to Hughes with the memo that just said, "HELP!" ${ }^{20}$ Hughes would also connect to Moyers on the updated bill, who agreed with Hughes that while some positive changes had been made, the bill still remained objectionable and $\mathrm{BOB}$, and the president, will continue to oppose the legislation. ${ }^{21}$ White would respond a few weeks later to Archibald noting that they had legislative specialists look over the bill, and administration lawyers still agreed the legislation was unconstitutional and created too much of an administrative burden on agencies. White ends by stating that he hopes Moss and the subcommittee will continue to work with them on overcoming objections. ${ }^{22}$ White had also responded to Moyers, saying, "I have not been bothered by Sam Archibald about this but it seems to me we ought to at least make it clear that our silence does not mean agreement. Additionally, I did not think it desirable to just say "no" but wanted to kind of preserve our "harmonious" working relationship by sticking poor old Norb [Schlei] with the duty of working with Sam." ${ }^{23}$ The ongoing conversations within the White House and between the administration and Congress is consistent in demonstrating the informal institutions at work within the legislative development process. While each side was firm in their positions, they were still open to input and negotiation on the bill. The president's strategy of private bargaining was already helping to move Moss toward changing some of the language in the bill. While the administration continued to press Moss on specific provisions within the bill, like the legal mechanism that would allow requesters to file lawsuits over being denied information, it seemed that the president's position was using these smaller provisional fights as a means of continuing

\footnotetext{
${ }^{19}$ Letter to Mr. Lee White, 2 August 1965: Office Files of Harry McPherson, folder: Office Files of Harry McPherson Executive Privilege, Box 22, LBJ Presidential Library.

${ }^{20}$ Letter to Mr. Sam Hughes, 4 August 1965, Office Files of Harry McPherson, folder: Office Files of Harry McPherson Executive Privilege, Box 22, LBJ Presidential Library.

${ }^{21}$ Memo to Bill Moyers, 13 August 1965: Office Files of Harry McPherson, folder: Office Files of Harry McPherson Executive Privilege, box 22, LBJ Presidential Library.

22 Letter to Sam Archibald, 27 August 1965: Office Files of Harry McPherson, folder: Office Files of Harry McPherson Executive Privilege, box 22, LBJ Presidential Library.

${ }^{23}$ Memo to Bill Moyers, 27 August 1965: Office Files of Harry McPherson, folder: Office Files of Harry McPherson Executive Privilege, box 22, LBJ Presidential Library.
} 
to deny acceptance of the legislation in any form. ${ }^{24}$ LBJ sought to keep the focus in the subcommittee, dragging out the development through endless arguments over language so the bill would never move forward. The president's strategy would help to effectively stop the bill, while he sought to direct congressional efforts over his larger agenda items. The strategy seemed to be working for Johnson until October 1, 1965 when the Senate passed Long's version, S. 1160, in a voice vote under unanimous consent, sending the bill to the House. ${ }^{25}$ The Senate just gave Moss momentum while rebuking the president's efforts to keep the bill from moving forward.

By the end of the year, Archibald was in communication with Moyers, discussing that the subcommittee would be taking up their version of the bill in January, which included different language that they had worked out with the DOJ that was not in the Senate version. ${ }^{26}$ Archibald warned Moyers that things were going to heat up and the administration needed to prepare, although he notes that he believed there was no version of the bill that would be acceptable to some in the administration. In referring to the differences in the House and Senate versions, he said, "But even those changes would not make the bill acceptable to those agency witnesses. In fact, I doubt whether any improvements in the present law would be acceptable to the Executive Branch holdovers." Archibald's letter prompted Moyers to contact White, noting, "This could be a potential time bomb," with White responding that the White House needed to, "be prepared to talk with House leadership, including Moss, in order to get the subcommittee to change the bill to something more acceptable." ${ }^{27}$ White and Moyers would strategize with Schlei and Hughes to come up with acceptable language for the bill. White argued they should sit

\footnotetext{
${ }^{24}$ Memorandum for the Record, "Justice Department Views on Current Draft of HR 5012." Folder: Alphabetical Files - 1965 - "Kass Memos," Box M-45. National Archives, Washington, DC.

${ }^{25}$ Press release from the Subcommittee on Administrative Practice and Procedure, Oct. 1, 1965. Folder: Executive Folder LE/FE 14-1, WHCF Box 44, LBJ Presidential Library.

${ }^{26}$ Letter to Mr. Bill Moyers, 13 December 1965: White House Central File, Subject File, folder: Executive Folder LE/FE 14-1, box 44, LBJ Presidential Library.

27 Memorandum for Bill Moyers, 17 December 1965: White House Central File, Subject File, folder: Executive Folder LE/FE 14-1, box 44, LBJ Presidential Library.
} 
down with Moss without delay and come to an agreement on a bill the administration would accept, so they, "would not be in the awkward position of opposing freedom of information." ${ }^{28}$ By this time, LBJ's original plan to stop the bill had failed, but the private bargaining with Congress was continuing to work in his favor, in particular of they could get Moss to an agreement on changing the language. Moss needed White House support in order to get House leadership to move forward when his bill made it through committee. While Moss had been successful with coalition building, the group of House Republicans was not enough to get the bill to the floor. The president and Moss were in the situation where they needed to work together on a compromise in order to get the best outcome for each.

After several month of negotiations, a deal was made with Moss and House leadership and the administration that would allow the House to move forward on passing the Senate version of the bill. Numerous agency Secretaries had followed DOJ's lead in opposing the bill as unconstitutional and an administrative burden, but Moss refused to include any of the language written by the DOJ, nor would remove the legal mechanism. The administration agreed with the nine exemptions to disclosures within the law, but the final deal came from Moss agreeing to allow the DOJ to help write the final committee conference report that clarified the law and provided directions on implementation to agencies and the courts. ${ }^{29}$ This agreement satisfied the DOJ officials claims of the bill being unconstitutional and brought the agency heads around by allowing greater control over the implementation process for FOIA requests. Democratic House leadership was satisfied and would support Moss in moving the bill forward to a floor vote. Using the Senate version unamended would mean one the House passed the bill, it would head to LBJ's desk. The question remained whether the president was willing to accept the deal.

\footnotetext{
${ }^{28}$ Memorandum for Mr. Norbert Schlei and Mr. Phillip Hughes, 15 January 1966: White House Central File, Subject File, folder: Executive Folder LE/FE 14-1, box 44, LBJ Presidential Library.

${ }^{29}$ Letter to Charles Schultze from Ramsey Clark, June 28, 1966. Folder: P.L. 89-487, 7/4/66, S.1160. Enrolled Legislation Box 36, LBJ Presidential Library.
} 
Until this point, Johnson had been operating under the assumption that he would be able to stop the FOI bill from moving forward and keep it languishing in Congress. There were no rules or procedures he was following in this strategy, and now his private bargaining with his own party leaders had broken down enough to allow the bill to move forward. While concessions were made to the administration in order to appease the department and agency administrators, including the lawyers at DOJ, the president himself remained the last remaining wildcard as no one in Congress or inside the White House knew for sure how he would respond once FOIA landed on his desk. LBJ was remaining quiet at this time, and the possibility existed that he would veto the bill. ${ }^{30} \mathrm{~A}$ veto was concerning for Moss as he knew he lacked the votes in the House to override a veto even with the tenuous coalition that he supporting the efforts. The political focus from the White House on Great Society programs, left FOIA as an outlier policy being pushed by Democratic members of Congress to check presidential power over control of information at a time that massive social and government reform policy was the focus.

On March 30, 1966 FOIA was voted out of the Moss Subcommittee and sent to the full Government Operations Committee for a vote. Moss maintained communication with various members of the White House during this period, including Moyers, demonstrating a collegial information sharing process where Moss was keeping to the agreement on the bill, and the Moyers began working from the inside to push LBJ to sign the bill when it came to him. By the end of the April, FOIA passed through the full committee and was set to go the House floor for a full vote. ${ }^{31}$ House Republicans used this opportunity to continue to attack Johnson of building a "screen of secrecy" in the executive branch and noted his silence as to whether he would sign FOIA. ${ }^{32}$ The political pressure was mounting as the 1966

\footnotetext{
30 Interview with Bill Moyers, conducted via email between March 17, 2015 and May 5, 2015.

${ }^{31}$ Press Release, House Committee on Government Operation, April 27, 1966. Folder: Freedom of Information Miscellaneous [1965-1966], Box M-25, Center for Legislative Archives, National Archives, Washington, DC. 32 Press Release, House Republican Policy Committee, 18 May 1966: folder: Credibility Gap 1966-1967, Press Secretary and Speech File 1947-1973, Press Releases, Agriculture 1966 to Press Releases, Crime 1973, box D6, Gerald R. Ford Presidential Library.
} 
midterm elections drew nearer and congressional Republican attacks became more fierce. Moyers pressed LBJ to use FOIA as a showcase bill, countering Republican attacks and make the argument for bringing greater transparency to government. ${ }^{33}$ Moyers and several other advisers conferred over options, which included a full signing ceremony featuring prominent members of Congress and the press, or using the Governor's Conference that Johnson would be attending on July $4^{\text {th }}$ as a backdrop to sign the bill. ${ }^{34}$ While close advisors to the president were discussing plans, Johnson remained silent. Moyers suggested one reason being Herbert Hoover's staunch opposition to the bill. While most other federal agencies had given tacit approval of FOIA after the deal on implementation was made, Hoover fervently argued directly to LBJ against his signing the bill. ${ }^{35}$

FOIA passed the House on June 20, 1966 with a unanimous vote of 306 to 0, with 126 members not voting. The final vote tally showing 207 Democratic and 99 Republicans supported the bill. ${ }^{36}$ FOIA was now on its way to the president's desk, and no one knew what LBJ would do. To complicate the situation more, the following week Congress adjourned for the $4^{\text {th }}$ of July recess, leaving Congress out of session for several weeks and providing Johnson the ability to use the pocket veto to kill the bill outright. From the final vote tally, it was clear that Moss did not have enough confirmed support to override a veto, and now leaving him unsure whether he and his Senate allies would be able get the bill through a second time, if they had to start over following a pocket veto. This situation again demonstrates the functionality of the informal institutions at work, providing the parallel and coordinating functions between Moss and Moyers, as well as the uncertainty of Johnson's behavior as he pivoted between

\footnotetext{
${ }^{33}$ Memo to Robert Kintner, 28 May 1966, White House Central File, Subject File, folder: Executive Folder LE/FE 141, box 44, LBJ Presidential Library.

${ }^{34}$ Memorandum for Bill Moyers, 15 June 1966: GEN FE 14 Records - Archives (11/22/63-5/25/65), folder: FE 14-1 (4/6/65-5/10/67), box 25, LBJ Presidential Library.

35 Interview with Bill Moyers, conducted via email between March 17, 2015 and May 5, 2015.

${ }^{36}$ The roll call vote count is available online through GovTrack.us, and can be accessed at http://www.govtrack.us/congress/votes/89-1966/h277. The final vote count is a glaring hole in the archives. From all the documents I have examined thus far, nothing accounts for why so many members did not vote. While I have several competing theories, as of this writing, I have no evidence so more research will need to be done.
} 
strategies in determining what his final response would be. The only clear aspect of this process was the decision made by LBJ and the White House to pursue a private strategy with Congress during the development stages of the process, and into the final stages, the president remained completely silent on his intentions, even to his own advisors. LBJ had through July $4^{\text {th }}$ to either sign, veto, or let the bill be pocket vetoed.

As Johnson left Washington for his Texas ranch over the July $4^{\text {th }}$ holiday, Moss and Archibald kept their pressure on various administration officials to convince the president to sign the bill. Archibald told White House counsel Milton Semer that LBJ should not repeat the mistake that Eisenhower made in 1958, where Archibald says he "muffed-it" in his response and issued a "weaselworded statement." ${ }^{37}$ Moss and Long both kept the pressure on, as well as many prominent members of the press who would reach out to Johnson during this time, some at the behest of Moyers. A June 24 memo to Johnson from special assistant to the president Robert Kintner relayed a phone call Kintner had earlier with Moss who urged the president to hold a signing ceremony to celebrate FOIA. Across the bottom of the memo in large letters, LBJ scrawled, "No Ceremony." ${ }^{38}$ The indication from the conversation and memo were not clear as to whether the president now planned to sign the bill but did not want a ceremony, or whether he planned to veto the bill. Regardless, he was clear about not wanting to make a show of it. Moyers notes that by the end of June, LBJ had "entered into a séance" with himself over what he should do with the bill. He had heard from all sides, most, including many within his administration and close advisors, urged him to sign the bill. Some, like Hoover, wanted the bill vetoed.

\footnotetext{
${ }^{37}$ Letter to Milton P. Semer, 20 June 1966: GEN FE 14 Records - Archives (11/22/63-5/25/65), folder: FE 14-1, Access to Records, box 25, LBJ Presidential Library.

${ }^{38}$ Confidential Memorandum for the President, 24 June 1966: Handwriting File Lyndon B. Johnson, folder: Handwriting-President Johnson June, 1966 (notes, instructions, doodles), box 15, LBJ Presidential Library.
} 
On the morning of July 4, with no fanfare or ceremony, LBJ signed FOIA and issued a signing

statement, following in Eisenhower's footsteps. Moyers would recount the moment by stating,

LBJ had to be dragged, kicking and screaming, to the signing... He hated the very idea of open government, hated the thought of journalists rummaging in government closets, hated them challenging the official view of reality. He dug in his heels and even threatened to pocket veto the bill after it reached the White House. Only the tenacity of a congressman named John Moss got the bill passed at all, and that was after a 12-year battle against his elders in Congress... He [Johnson] signed "the f-ing thing" as he called it and then set out to claim credit for it. ${ }^{39}$

Moyer would recount that in the end, Johnson was pragmatic and loved the game of legislative politics, so when he knew that Moss had won and FOIA was coming to his desk, he wanted to be on the right side. ${ }^{40}$ Moyers noted that it was not unusual for LBJ to keep his positions secret and keep everyone guessing until he had fully made up his mind.

The White House issued a signing statement with the bill, providing the administration's position on the issue, doing exactly what Moss had pleaded with the White House not to do. The statement gave lip service to the importance of the legislation, discussing the need for government transparency for democratic health, but then goes on to assert,

$[T]$ he welfare of the nation or the rights of individuals may require that some documents not be made available. As long as threats to peace exist, for example, there must be military secrets...Moreover, this bill in no way impairs the President's power under our Constitution to provide for confidentiality when the national interest so requires. ${ }^{41}$

Much like Eisenhower, Johnson signed the bill and issued a statement that reiterated administrative control over information in the national interest. This assertion, coupled with the DOJ input on implementation, provided the president with a cushion and near complete control over administering the new open records program as well as continuing to have control over refusing to provide certain information.

\footnotetext{
39 Moyers 2005, 157-158.

40 Interview with Bill Moyers, conducted via email between March 17, 2015 and May 5, 2015.

${ }^{41}$ Statement by the President upon signing S. 1160, 4 July 1966: Reports on Enrolled Legislation, P.L. 89-465 to P.L. 89-491, 6/22/66 to 7/4/66, folder: P.L. 89-487 S. 1160, box 36, LBJ Presidential Library.
} 
When it comes to decision making within the framework of the informal institution's functions, LBJ provides insight. The completing function is shown through the haphazard bargaining process that underlies the struggles to influence policy during development and the political influences in the moment. There are no formal rules written for how the president and Congress choose to engage (or not) when it comes to policy development and passage, so we know there are underlying reasons for when a president does choose to engage and in what ways. The parallel function displays how both members of Congress and staff, along with the president and staff engage inter-institutionally. Congress is following formal rules and processes when it comes to committees and votes within both chambers, but the parallel function gives us a look at when and in what ways the White House intervenes outside the legislative process at play to then interfere with that process. The coordinating function shows how multiple White House agencies, advisors, and the president engaged with Congress during the development and passage over FOIA. What stands out with the example of Johnson is that he pursued a private bargaining strategy with Congress as it would not be politically feasible for him to openly oppose a Democratically controlled Congress on an issue that Republicans were attacking him over. So, Johnson worked with party leadership in the House and had his people working with Moss directly to stop the forward momentum and kill the bill. However, Johnson was facing another problem with Congress, which was his Great Society agenda. As Moyers noted, Johnson needed the support in Congress to enact his agenda, and he needed Moss and the FOIA coalition to back him on a lot of policy issues, therefore it only made sense to sign FOIA, credit claim on it, and keep his congressional coalition happy rather than pick a fight and lose everything he had been working on. Finally, it was clear that an influencing factor in Johnson's decision making was administrative control over implementation in shaping what the FOIA process would actually be, as well as providing an argument to continue to claim confidentiality on information as he saw fit. 


\section{Nixon Attempts, Ford Tries...Both Fail}

In contrast to Johnson, Nixon came into office facing an opposition Congress controlled by Democrats and with FOIA having been fully implemented in 1967. While Nixon paid a lot of attention to control over information and use of executive privilege, especially in his dealings with Congress, his agenda never focused on FOIA. However, by the time Nixon's reelection campaign is well underway, congressional investigations stemming from use of executive privilege and control over information led Congress to become focused on fixing what they viewed were issues with FOIA. Nixon attempted to address public information issues through unilateral action in claiming to fix problems with the current classification system, but the executive order served to recentralize power and control into the Oval Office instead of with each agency. ${ }^{42}$ The House Subcommittee on Foreign Operations and Government Information (FOGI) began developing legislation that would amend FOIA and address the issues raised by Nixon's executive order. ${ }^{43}$ The subcommittee was already scheduling hearings and investigations into what Congress viewed as continued obstruction to information from the administration. ${ }^{44}$ The FOGI subcommittee actions in the House bled over to the Senate where Senator Sam Ervin (D-NC) began demanding administration officials testify before Congress about Nixon's use of executive privilege to prevent officials from appearing before Congress. ${ }^{45}$ The exchange with Ervin and the president became common during this time, so common that Nixon's White House Counsel John Dean had a standard

\footnotetext{
42 Richard Nixon: "Executive Order 11652-Classification and Declassification of National Security Information and Material," March 8, 1972. Online by Gerhard Peters and John T. Woolley, The American Presidency Project. https://www.presidency.ucsb.edu/documents/executive-order-11652-classification-and-declassification-nationalsecurity-information.

43 The Moss Subcommittee was made a permanent subcommittee in 1964, expanding the scope and naming it the Subcommittee on Foreign Operations and Government Information (FOGI). Moss remained as Chair until 1972, when the Chair was taken over by Rep. William Moorhead (D-PA), but Moss remained on the committee until he retired in 1979.

${ }^{44}$ Memo to John Dean from Margita White, April 19, 1972. Folder: FOIA \#2. WHCF: Buzhardt, Box 15, Richard M. Nixon Presidential Library.

45 Letter to Richard Nixon from Sam Ervin, April 21, 1972. Folder: Executive Privilege - Congressional Folder 5. WHCF: Buzhardt, Box 14, Richard M. Nixon Presidential Library.
} 
response to members of Congress requesting information or testimony, where Dean would reference, "long established historical precedents," that would allow him to infer executive privilege without actually invoking it. ${ }^{46}$ Dean's response to Ervin and other members of Congress to deny testimony or information falls squarely into the completing function of an informal institution as there existed no rule or structure for executive privilege and its use, as the modern use was a construction from Eisenhower. Past precedent is a guide to help make sense of an extra-constitutional power like executive privilege, but Nixon pushed far beyond what his predecessors had done in using this privilege, broadening claims to encompass all executive branch communication for whatever reason the president deems necessary. Even once the Supreme Court ruled in United States $v$ Nixon in 1974 that legitimized executive privilege as a constitutional presidential power, the continued use remains a legal gray area with any formal rules and processes open to interpretation.

Nixon's problems with Congress only compounded into his second term. Like Johnson, Nixon faced a much larger agenda that began to dominate his administration, none of which was positive. Nixon was defensively dealing with numerous issues, including the Watergate scandal, executive privilege, targeting White House leaks to the press, all of which provides the context to understand why Congress began to move on amending FOIA and why the amendment issues were not necessarily of importance to Nixon. For members of Congress, Nixon's continued use of executive privilege to deny information and testimony became a central concern that demanded a legislative solution. By February 1973, the House Government Operations Committee began to move forward on H.R. 4938, an amendment to FOIA that would require any congressional request for information be fulfilled within 30

\footnotetext{
${ }^{46}$ Letter to Sam Ervin from John Dean. Folder: Executive Privilege - Congressional Folder 5. WHCF: Buzhardt, Box 14, Richard M. Nixon Presidential Library. NOTE: at the Nixon Presidential Library there are dozens of letters from Dean to various members of Congress all with the same or similar response, where he mentions inherent presidential power and historical precedents without ever specifically saying 'executive privilege' in his denial of information or testimony to Congress.
} 
days unless the president submits to Congress a statement that specifically invokes executive privilege.

The bill clarified executive privilege,

Executive Privilege shall be invoked only by the President and only in those instances in which the requested information or testimony contains policy recommendations made to the President or agency head and the President determines that disclosure of such information will seriously jeopardize the national interest and his ability or that of the agency head to obtain forthright advice. ${ }^{47}$

The message coming from Congress was clear, they were no longer interested in tolerating continued obstruction to information and testimony. The politics of this moment worked in favor of congressional Democrats as the Watergate scandal grew and the Senate Watergate Committee began their work. House Democrats no longer seemed worried about olive branches to the White House, instead opting to go head on at the president. Over the next few months, requests from Congress for administration officials, in particular John Dean, to appear before various committees to discuss executive privilege grew, along with multiple new bills introduced to amend FOIA in order to increase transparency. In several bills, Congress began to tie agency and department funding to compliance with requests for information and testimony. ${ }^{48}$ Internal White House conversations among advisors, counsels, and the Office of Legal Counsel (OLC) over these bills asserted they violated the separation of power doctrine and were unconstitutional. All of Nixon's advisors quickly recommended that a veto strategy be pursued, which Nixon agreed to. ${ }^{49}$ That veto strategy was never implemented as none of these moved through committee, but were being used by Congress to send clear messages to the White House, as attention focused more toward the Watergate scandal.

\footnotetext{
${ }^{47}$ H.R.4938, "To amend the Freedom of Information Act to require that all information be made available to Congress except where Executive privilege is invoked," Feb. 28, 1973. Folder: Executive Privilege - Congressional Declinations, Folder 5. WHCF: Buzhardt, Box 13, Richard M. Nixon Presidential Library.

${ }^{48}$ Memo to Leonard Garment from Leon Ulman, July 16, 1973. Folder: Executive Privilege - General, Folder 11. WHCF: Buzhardt, Box 13, Richard M. Nixon Presidential Library.

${ }^{49}$ Memo to Leonard Garment from Bud McFarlane, July 16, 1973. Folder: Executive Privilege - General, Folder 11. WHCF: Buzhardt, Box 13, Richard M. Nixon Presidential Library; Memo to Leonard Garment from Mike McKivett, July 16, 1973. Folder: Executive Privilege - General, Folder 11. WHCF: Buzhardt, Box 13, Richard M. Nixon Presidential Library.
} 
Over the next year, the FOGI subcommittee continued to examine needs and ways of amending FOIA, resulting in March, 1974 with a cooperative bill, H.R. 12471 to amend FOIA by increasing disclosure policies and enforcement procedures. The bill combined ideas from multiple other bills that had been previously introduced, but focused change on the administration of the law, including agency reporting requirements and annual assessment reports being made public. The White House immediately objected to the bill, calling it "unacceptable," but also noted that the Senate Judiciary Committee was working on a companion bill that could be better. ${ }^{50}$ While many within the administration were willing to work with the Senate to get a more favorable bill, including Nixon, the problem was no administration official or the president were willing to compromise on any FOIA bill that they saw as weakening presidential authority. Talks between the White House and Senate quickly broke down with little to no communication existing between them. The result was the Senate passing its own FOIA amendment bill in May, 1974 that contained much stronger provisions than the House version, all of which Nixon was opposed to. ${ }^{51}$ The two FOIA amendment bills moved to a conference committee to work out the details.

Many within the White House were determined to see the bill fail and advised Nixon to pursue a veto strategy of outright opposition, arguing the bill was too objectionable to win over enough Senators to override his veto. ${ }^{52}$ These discussions noted the conference committee was not favorable to working with the White House and were wanting a quick timeline to be done by mid-July, therefore leaving Nixon little hope of influencing the final bill language. However, despite near unanimous advice from officials, Nixon opted for a different veto bargaining approach, seeking to reach out privately to the

\footnotetext{
50 Memo to Jerry Jones from Powell Moore, May 20, 1974. Folder: EX LE Legislation [39 of 39, February-July 1974]. WHCF: (LE) Legislation, Box 7, Richard M. Nixon Presidential Library.

${ }^{51}$ Memo to Richard Nixon from Roy Ash, June 27, 1974. Folder: [EX] FE 14-1 5/1/74-8/9/74. WHCF: FE (Federal Government) Box 22, Richard M. Nixon Presidential Library.

52 Memo to Richard Nixon from Ken Cole, July 2, 1973. Folder: [EX] FE 14-1 5/1/74-8/9/74. WHCF: FE (Federal Government) Box 22, Richard M. Nixon Presidential Library.
} 
conference committee, advising them of the White House's specific objections, and only threaten to use a veto if the bill was not rewritten. ${ }^{53}$ The largest problem facing Nixon's ability to successfully veto bargain with the conference committee was the political climate. By the end of June 1974, the Supreme Court was weeks away from delivering their decision in United States $v$ Nixon, along with the resulting congressional investigations leading Nixon to the brink of impeachment, and ultimately his decision to resign in early August. Nixon lacked credibility and was losing public opinion, so he had lost power in negotiating with Congress, making his threats to veto the FOIA amendment bill weak at best. He attempted to work with the conference committee and only make a veto threat if that did not work, but he lacked any other option by that time, and his position was weak. Nixon was smart enough to not pursue a public veto bargaining strategy as he lacked public trust on government transparency, therefore going public would most likely harm his influence instead of help. His decision to pursue a private veto threat strategy would keep the spotlight off the issue and his actions, and would initially aid his successor. Regardless of Nixon's efforts or plans, he would resign from office before the conference committee would finish their work on the FOIA amendment bill.

Gerald Ford was sworn in as president on August 9, 1974 and was faced with the immediate problem of dealing with the FOIA conference committee, which was led by Senator Ted Kennedy (D-MA) and Roman Hruska (R-NE), and also included House members Moss and Moorhead. Within a few days of becoming president, Ford received notice from his Office of Management and Budget (OMB) Director, Roy Ash, that the conference committee would be voting on a final version of the FOIA bill within a few days. He advised Ford to reach out to the committee, requesting more time so that he could offer a response and position on the bill. ${ }^{54}$ Ash noted that most agencies and advisors all believed the bill could

\footnotetext{
53 Memo to Richard Nixon from Roy Ash, June 27, 1974. Folder: [EX] FE 14-1 5/1/74-8/9/74. WHCF: FE (Federal Government) Box 22, Richard M. Nixon Presidential Library.

54 Memorandum for Gerald Ford from Roy L. Ash, 12 August 1974. Folder: Legislative Issues Pending (1), William E. Timmons Files Box 4. Gerald R. Ford Presidential Library.
} 
not be fixed to overcome their objections to the bill usurping executive authority and were recommending that Ford clearly make a threat to veto. Ash believed that while the committee would most likely not be willing to amend the bill, he thought that Kennedy and Moss would at least be willing to hear Ford out and grant him some time. Ash was concerned that it would not look good for Ford to veto the FOIA bill in the fallout of Nixon's resignation, and was hoping that Ford would be able to build a better working relationship with Congress.

Ford determined the best strategy to move forward was to ask the conference committee to wait on passing the final bill and allow him some time to provide his own input. William Timmons, assistant on legislative affairs told Ford that Hruska was asking for a signal from the White House so he could bring Ford's position to the committee. ${ }^{55}$ Ford's Attorney General William Saxbe reached out the conference committee to ask for more time. Inside the administration there was a division between advisors where many wanted Ford to bargain with Congress on the FOIA bill, while most of Nixon holdovers advised Ford to just veto the bill as Nixon would have done. Ford sided with his advisors as they agreed on the political viability of trying to make a fresh start with Congress, and especially over a bill focused on transparency. Ford seemed confident that Congress would grant him some time and more favorable conditions. ${ }^{56}$ Ford's strategy paid off as Kennedy said the committee would be willing to provide Ford an additional week to provide his feedback, before they cast a final vote on August $20 .{ }^{57}$ Over the following week, Timmons led the effort from the White House to work with the committee on

\footnotetext{
${ }_{55}$ Memorandum for Gen. Alexander Haig, 13 August 1974: folder: Legislative Issues Pending (1), William E. Timmons Files, Freedom of Information Act Veto to Meetings with Congressional Leaders Sept. 1974, Box 4, Gerald R. Ford Presidential Library.

${ }^{56}$ Memo to The President from Philip Buchen, Aug. 13, 1974. Folder: FG 17 Department of Justice 8/9/74-9/30/74, WHCF Subject File Box 86. Gerald R. Ford Presidential Library.

${ }^{57}$ Memo for William Timmons from Patrick O'Donnell, Aug. 14, 1974. Folder: Freedom of Information, 6/188/16/74, Congressional Relations, O'Donnell and Jenckes Files (1971) 74-76, Box 5. Gerald R. Ford Presidential Library.
} 
the issues the president found troubling, but the committee did not seem interested in changing the language of the bill.

The day before the deadline, Timmons reached out to Ford, informing him of their lack of progress and asking the president to get directly involved, believing he could have an impact with the committee. Timmons had already drafted a letter from Ford to the committee, detailing their concerns and making recommendations. He asked Ford to sign and send in the letter, which Ford did the following day. Ford thanks the committee for giving him the time to provide input, as well as noting the success of FOIA and the need to make improvements, but he also warned of problems. The letter states,

There are, however, more significant costs to government that would be extracted by this bill - not in dollar terms, but relating more fundamentally to the way Government, and the Executive branch in particular, has and must function. In evaluating the costs, I must take care to avoid seriously impairing the Government we all seek to make more open. I am concerned with some of the provisions which are before you as well as some which I understand you may not have considered. I want to share my concerns with you so that we may accommodate our reservations in achieving a common objective. ${ }^{58}$

Ford detailed three specific provisions within the bill that he argued were unconstitutional by interfering with the president's authority to administer the executive branch. The three objectionable provisions were the same ones that Nixon opposed and was willing to veto the bill because of them, however, in his letter Ford never makes an explicit veto threat. Ford did make a strong argument that he is willing to work with Congress, and has offered alternatives to the provisions he objected to, but implied within the letter there was a limit to what he would accept. Within the first two weeks of his administration, and based in part on the timing of the conference committee, Ford found himself instantly needing to defend several positions on legislation that Nixon had taken which has now transferred to him. With the FOIA amendments, Ford decided to focus on that particular legislation due to the subject matter and the politics of the moment. It was not lost on Congress, and in particular to Moss and several members of

\footnotetext{
58 Letter to William Moorhead and Edward Kennedy from Gerald Ford, Aug. 20, 1974. Folder: Legislative Issues Pending (1), William E. Timmons Files, Box 4. Gerald R. Ford Presidential Library.
} 
the conference committee that Ford, and his now Chief of Staff Rumsfeld, were proponents of the original legislation and supported its passage in 1966.

The letter worked to grant Ford more time and consideration by the committee, who postponed their vote. A month later, Ford received a letter signed by Kennedy and Moorhead responding in detail to the concerns raised in his letter and their points of disagreement. The letter opened with Kennedy and Moorhead thanking Ford for his personal interest on the issue and bill, then continued with,

And we appreciate your recognition of the fundamental purposes of this milestone law and the importance you attach to these amendments. They of course would provide support for your own policy of "open government" which is so desperately needed to restore the public's confidence in our national government. ${ }^{59}$

Kennedy and Moorhead continued to note how the committee deliberated on Ford's comments, talked with various administration officials, and revisited the language of the bill. They note the committee did address several of Ford's sticking points, changing the language to reflect issues raise by the administration and in what specific ways. The letter ends with Kennedy and Moorhead stating they hope the changes will make the bill acceptable to Ford as they have met his concerns and that the committee plans to move forward on a final vote.

The internal White House response to the letter was mixed. Some, like general counsel Douglas Metz argued that the changes were acceptable and the president should say he will sign the bill. Metz noted there being no guarantee they could do any better with Congress, now or in the future, and that the original bill passed with overwhelming majorities. Metz also argued that the public was deeply distrustful of the administration right now, and Ford would boost his public standing by supporting the bill and use it to show his position in favor of transparency. ${ }^{60}$ Other White House officials noted that several of the conference committee Republics had not signed off on the final committee report,

\footnotetext{
59 Letter to Gerald Ford from Edward Kennedy and William Moorhead, Sept. 23, 1974: folder: Legislative Issues Pending (1), William E. Timmons Files, Box 4. Gerald R. Ford Presidential Library.

60 Memo to Stanley Ebner from Douglas Metz, Aug. 24, 1974. Folder: Freedom of Information, 8/19-9/30/74, Congressional Relations, O'Donnell and Jenckes Files (1971) 74-76, Box 5. Gerald R. Ford Presidential Library.
} 
arguing their support would be essential in getting Congress to sustain a veto. In the end, the only Republican not to sign the report was Hruska, who would be the focus for Ford in attempting to get the Senate to sustain his veto of the bill. ${ }^{61}$ Ford was counseled that many agencies, including DOJ, State Department, Defense Department, and the CIA were all opposed to the bill and recommended he veto. His advisors argued that a veto would be overridden in the House but they thought they could win over enough Senators to sustain.

In the coming days Congress would pass the final version of the FOIA amendment bill. The head of OLC, Antonin Scalia, sent a memo out that included a draft memo of a veto message Ford could use, which Scalia believed would make a strong case and be supported by the public. He believed Ford could save face with the veto of the bill by using his message to focus on objectionable language and offer specific compromises in calling on Congress to accept the language provided in the veto message. ${ }^{62}$ Shortly after passing the bill, Congress adjourned for a month-long recess to carry through the midterm election in November. This provided Ford with an additional opportunity, much like LBJ had, where he could opt to pocket veto the bill and let it die outright, as opposed to a traditional veto and then fighting to sustain it in the Senate. It seemed by this point that for Ford, the option of signing the bill and moving on with a signing statement in the same manner that both Eisenhower and Johnson did no longer existed. At this point and with the support of almost all of his advisors and department heads, Ford was going to veto the bill either way. ${ }^{63}$ Ford decided his best option was to veto the bill and in his veto message to Congress include specific language he wanted changed out, then call on Congress to immediately introduce and pass a new bill with Ford's language in the bill and he would sign it. In

\footnotetext{
${ }^{61}$ Memo to Gerald Ford from Kenneth Cole, Sept. 25, 1974. Folder: Legislative Issues Pending (2), William E. Timmons Files, Box 4. Gerald R. Ford Presidential Library.

62 Memo to Geoffrey Shepard from Antonin Scalia, Oct. 3, 1974. Folder: Freedom of Information Act Amendments H.R. 12471 (1), Frederick Lynn May, Box 27. Gerald R. Ford Presidential Library.

63 Memo to Gerald Ford from Ken Cole, Oct. 9, 1974. Folder: Freedom of Information Act Amendments H.R. 12471

(2), Frederick Lynn May, Box 27. Gerald R. Ford Presidential Library.
} 
breaking with his predecessors by pursuing this strategy, Ford was also moving the process into the public, by issuing a veto and his statement, he believed he could win the public over and provide additional pressure on Congress to compromise.

Ford issued his veto on October 17, 1974, and included in his veto message to Congress his specific objections to certain provisions within the bill while offering his own language that he would find acceptable. At the core of his message, and in line with Scalia's argument, Ford believed the language of the bill to be an unconstitutional usurpation of executive power by Congress. He ended the statement with,

It is only my conviction that the bill as enrolled is unconstitutional and unworkable that would cause me to return the bill without my approval. I sincerely hope that this legislation, which has come so far toward realizing its laudable goals, will be reenacted with the changes I propose and returned to me for signature during this session of Congress. ${ }^{64}$

Ford was attempting the thread the needle with both public opinion and with Congress in order to try to achieve a different legislative outcome. He knew he best course of action was to convince enough Senator's to sustain his veto so he could press Congress to agree to his additional compromises if they chose to take up the bill again. Ford took the additional step to send congressional leadership, along with Kennedy and Moorhead, letters that included more details on what he would accept on a compromise FOIA bill. Ford implored Congress to work with him on this issue, stating,

While I realize we have had our differences on this bill, I think they are few compared to the many compromises and the substantial agreements which have been worked out over the past several months. I ask your further help and cooperation so that we may accomplish our common goal of producing viable freedom of information legislation before the close of the $93^{\text {rd }}$ Congress. ${ }^{65}$

\footnotetext{
${ }^{64}$ Message to the House of Representatives from Gerald Ford, Oct. 17 1974. Folder: Freedom of Information Act Amendments, Robert T. Hartmann Files, Box 12, Gerald R. Ford Presidential Library.

65 Letters to Carl Albert, James O. Eastland, Edward M. Kennedy, William S. Moorhead, Oct. 25, 1974. Folder:

Freedom of Information Act Amendments, Robert T. Hartmann Files, Box 12. Gerald R. Ford Presidential Library.
} 
Ford was hoping to avoid the need to fight over sustaining the veto if he could convince congressional leadership to work with him instead.

While Ford was publicly trying to convince congressional leaders to work with him, he was privately conducting outreach to congressional Republicans seeking their support in sustaining his veto. Ford asked Hruska to quickly introduce Ford's version of the FOIA bill so that Senate Republicans could argue to move forward with that version instead of bothering with a veto override vote on the other version. ${ }^{66}$ The main issue was that Congress was out of session until November 18, and no one knew how quickly they would move on the FOIA override when they got back. A confounding issue adding to the situation was the midterm election itself. While the Democrats were already in control of Congress, a sweeping victory would make the situation worse for Ford instead of better. As was likely to be the case, the public rejection of Nixon could prove to make Ford's ability to influence difficult. Included with this was Ford's pardon of Nixon the month before. Congressional Democrats were already unwilling to work with Ford, as his advisors filled him in on discussions with Kennedy who was not interested in compromising on the language. ${ }^{67}$

Ford had taken on a dual bargaining strategy, the first being his desire to work with congressional Democrats on getting their support for an alternative bill that would be closer to what he wanted, yet congressional Democrats were no longer willing to entertain Ford's position on the bill, as they did not agree with his assessment of it being unconstitutional. ${ }^{68}$ While this strategy was largely public with the hope of swaying public opinion to help convince congressional Democrats to work with him, Ford was pursuing a private strategy with Senate Republicans as he reached out directly to

\footnotetext{
${ }^{66}$ Memo to Doug Marvin and J.C. Argetsinger from Patrick O'Donnell, Oct. 29, 1974. Folder: Freedom of Information 10-12/74, Congressional Relations, O’Donnell and Jenckes Files (1971) Box 5. Gerald R. Ford Presidential Library.

${ }^{67}$ Memo to William Timmons, Tom Korologos, and Max Friedersdorf, Nov. 4, 1974. Folder: Freedom of Information 10-12/74, Congressional Relations, O'Donnell and Jenckes Files (1971) Box 5. Gerald R. Ford Presidential Library. 68 Memo to Phil Areeda and William Timmons, Nov. 11, 1974. Folder: Freedom of Information 10-12/74, Congressional Relations, O’Donnell and Jenckes Files (1971) Box 5. Gerald R. Ford Presidential Library.
} 
individual members of Congress asking them to sustain his veto and support his version of the bill. ${ }^{69}$

Over the next several works, Ford would continue to reach out to Senators asking for support, while the midterm election ushered in net gains in seats for Democrats, further weakening his position. Ford was able to gain a bipartisan group of seven Senators, including Hruska and Eastland, to send out a Dear Colleague letter to all members of the Senate, imploring them to sustain the veto while supporting a vote on a new FOIA amendment bill that included the president's language. ${ }^{70}$ The letter was a lastminute plea for support as the Senate was getting ready to vote on the veto override, which stated, In enlisting your support, we wish to make it clear that a vote in support of the President's veto does not, in any way, reflect a rejection of a commitment to the ideals of the Freedom of Information Act. Indeed, it is our conviction that the citizen should be granted the fullest access to the records of the Federal agencies that the right of privacy and effective government will permit.

The language and tone of the letter proved problematic as much of the positioning offered sounded very similar to Nixon's position on executive privilege, in making an argument of the president's right for national security reasons and in the public interest to keep information confidential, while simultaneously offering support for the transparency provided by FOIA. The letter missed the mark with most members of Congress at precisely the time they were seeking to separate themselves from Nixon in providing greater checks on the presidency in the fallout of the Democratic seats gained in the midterm election. The Dear Colleague had little impact as the House and Senate voted to override his veto, making the FOIA amendments law.

\footnotetext{
${ }^{69}$ Letter to Congressman John J. Rhodes, Nov. 16, 1974. Folder: Freedom of Information Act (1), William E. Timmons Files, Box 4. Gerald R. Ford Presidential Library.

70 Dear Colleague Letter, Nov. 19, 1974. Folder: Freedom of Information 10-12/74, Congressional Relations, O'Donnell and Jenckes Files (1971) Box 5. Gerald R. Ford Presidential Library. The signatories of the letter were Senators James Eastland, Roman Hruska, John McClellan, Robert Griffin, John Stennis, Bill Brock, and Robert Taft, Jr.
} 


\section{Conclusions}

The purpose of this paper was to examine the president's role in the legislative process as tied to being an informal institution as established by Azari and Smith. The US Constitution establishes the institutions of government, steeped in formal roles and processes, but the Constitution is also silent on specifying many of these roles, especially when it comes to the presidency. The lack of formal role has given rise to norms that act as informal institutions, giving a focus to understanding the functionality of American politics as an informal system operating within a formal structure. Shifting our attention to these informal functions gives us insight into understanding an issue like presidential influence in the legislative process to better determine when, why, and in what ways presidents get involved and utilize their veto power with Congress. I argue that the president's role in the legislative process meets all three functions of Azari and Smith's informal institutions model, and provided evidence through the case study of FOIA, as handled by Johnson, Nixon, and Ford. By examining the role of veto threats or veto bargaining as informal institutions, we can shed light on specific factors that help explain presidential decision making that may be overlooked or missed through different types of analysis.

In looking at the completing function that fills gaps in the formal rules or procedures, we can understand that any role the president takes in directly working with Congress on legislation moves outside the Constitutional framework of the veto. The veto power provides the president to ability to say no to a bill if they choose, but establishes no formal role when it comes to seeking influence or in using veto threats to get a desired result from Congress. Beyond that point, by using the informal framework, we can better understand the motivating factors that lead presidents to engage with Congress over policy development to begin with. At any given time, even in a polarized climate, Congress is working on dozens, if not hundreds, of different bills incorporating a host of issues. Moving 
past the agenda setting literature, this framework gives insight into what contributing issues led the president to engage an in what ways.

With the FOIA example, we can understand that Johnson opposed FOIA while being confident he could work with his party in preventing the bill from moving through Congress. He was already working heavily with Congress on the Great Society agenda, and FOIA seemed like a minor issue in comparison, but his need to work with the Democratic coalition in Congress to support his agenda made it harder for him to stop FOIA. As FOIA continued to move through the process, Johnson found himself constrained by the politics of the moment, as he could not publicly fight against his own party in Congress on an issue of transparency while Republican's were branding him with a credibility gap. Ultimately he signed FOIA for these same reasons, to keep his coalition in Congress intact, while not having to publicly take a stand against transparency. When looking at the Nixon and Ford case, by the time Congress was moving on the FOIA amendments, Nixon was in a precarious situation of his own making. Not only was he facing an opposition Congress controlled by the Democrats, but the Watergate scandal coupled with his sustained use of executive privilege to deny Congress information and testimony had led Nixon to having very little influence with Congress. Nixon could not publicly veto threat the FOIA amendments at the very time he was being tried in the public arena for all of his underhanded activity. He sought to privately influence Congress on a bill that would be more acceptable, but was never able to. Ford was in an even worse position as the excesses of Nixon hung around his neck. Yet Ford took a private approach to work with the conference committee on altering the final bill, which he was successful in part in doing. His continued objection to certain provisions of the bill left him in a place where he pursued a dual strategy of trying to publicly work with Congress on a compromise bill that would sustain his veto, while privately trying to convince individual members of Congress to support his veto and alternative plan. Ford's strategy ultimately proved useless as Congress 
overrode his veto. The context of the situation helps clarify the important factors of the informal role the president plays in policy making.

Connected to the completing function is the parallel function where formal rules inform and regulate the informal norms of behavior. The president's role within the policy making process is influenced by the formal structures of Congress, an institution heavily impacted by formal rules and procedures. The president can then use the formal process of legislative development to plug into Congress at various junctures where applicable to influence the process favorably. With the case of FOIA, the issue had become institutionalized in 1955 with the create of the Moss Subcommittee in the House, which was pursuing its mandates by conducting investigations, holding hearings, seeking input and legislating. Johnson found himself standing opposed to the Moss subcommittee work he had once supported as Senate Majority Leader, but the process the subcommittee was using gave the president the ability to weigh in at the subcommittee level with the hope of stopping any FOIA bill from moving forward. It was largely at this level of the formal congressional process where Johnson was ultimately able to influence the final version in compromising with Moss on the committee report and control over implementation that helped lead to his signature instead of his veto pen. Nixon and Ford fared worse, in part due to Nixon's mounting problems that led him to largely ignore the FOIA amendment bill until it was close to passing. Once Nixon finally sought to inject himself into the process, the bill was passing and he lacked the political standing, in particular on that issue, to make a difference. While he tried to take a veiled veto threat approach in addressing members of Congress privately, his strategy was not fruitful, followed quickly by his resignation. Ford stepped into the process at the end point of the formal process in Congress, which was at the conference committee stage. While successful at changing the language of the bill, it was not enough to win his approval. While the process then moved into the more traditional veto bargaining stage, Ford used a dual approach seeking the same outcome, yet with both approaches proving to fail. The parallel function provides insight into how, when, and why the president 
will seek to intervene into the formal legislative roles of Congress. Different points of the process can yield different strategies in which the president can seek to influence, like seeking a private bargaining strategy over going public.

The coordinating function provides for the integration of multiple intersecting institutions. This is clear as we consider how the informal norms structure the relations between Congress and the president. Even just within the executive branch, we can better understand how the coordinating function provides a process by which the president seeks input from multiple sources on any policy issue and coordinate those efforts through specific staff as well as themselves. We saw how Johnson was getting input from various agencies and offices that helped to influence his decision making during the development process of FOIA, officials he used to help justify his positions. Both Nixon and Ford followed suit, and while multiple agencies advised Nixon to take a firm stand in threatening to veto the FOIA amendments, he chose a private bargaining strategy, the same strategy Ford began using while receiving much of the same advice. Ford continued to gain input from various officials and advisors leading him to pursue a dual strategy that ultimately failed for him. Inter-institutional relations are clarified by the informal coordinating function as well, where we can see with the case of FOIA that Congress held the offensive strategy while the president largely played defense. The president was the one responding to what Congress was doing as opposed to forcing Congress to respond to them. Even when it came to more explicit veto threats, and Ford's eventual use of the veto, Congress was still in control of the issue and policy making process. The president was constrained in behavior and actions by Congress, so while the same parallel function provided opportunities for the president to intervene in the legislative process, the coordinating function, at least the in FOIA case created constraints on presidential behavior, limiting the options available to largely develop a strategy of response.

One last point I wish to make when placing the case of FOIA into the informal institutions model is the issue of administrative control. It became clear in examining the case, most stark with Johnson 
and Eisenhower, is that part of the decisions making and behavior of the president was influenced by maintaining control over the administration and implementation of FOIA. This distinction becomes even more stark when examining the past 50 plus years of FOIA implementation and amendment, is that while Congress won the legislative victory of getting the bill passed, and continued to have oversight and make amendments, the president won control of implementation and administration. Both Eisenhower and Johnson made explicit in their signing statements that regardless the president maintained control over information, and that power Congress could not take. This was the argument made by both Nixon and Ford in their reasoning for opposing the amendment bill. If the president has the ability to control implementation, promulgate bureaucratic rules, and maintain denial of access power, then was there much risk in fighting against FOIA? Johnson clearly believed he could stop the bill from hitting his desk and keep the issue away, yet he failed to do so, but his signature came about not just because of political expediency in keeping his coalition happy, but also in knowing he could still control the flow of information. One factor of interest that would need to be added into future calculations when determining presidential support or opposition to legislation would need to include an understanding of administrative control and implementation. 


\section{References}

Azari, Julia R. and Jennifer K. Smith. 2012. "Unwritten Rules: Informal Institutions in Established Democracies." Perspectives on Politics 10(1): 37-55.

Baron, Kevin M. 2019. Presidential Privilege and the Freedom of Information Act. Edinburgh, SCT:

Edinburgh University Press.

Cameron, Charles M. 2000. Veto Bargaining. Cambridge, MA: Cambridge University Press.

Cameron, Charles M. and Nolan McCarty. 2004. "Models of Vetoes and Veto Bargaining." Annual Review of Political Science 7: 409-435.

Conley, Richard S. 2003. "George Bush and the $102^{\text {nd }}$ Congress: The Impact of Public and "Private" Veto Threats on Policy Outcomes." Presidential Studies Quarterly 33 (Dec.): 730-750.

Conley, Richard S. and Amie Kreppel. 2001. "Toward a New Typology of Vetoes and Overrides." Political Research Quarterly 54 (Dec.): 831-854.

Edwards III, George C. 1990. At the Margins. New Haven: Yale University Press.

Foerstel, Herbert N. 1999. Freedom of Information and the Right to Know. Westport: Greenwood Press.

Goren, Lilly J. 2013. "The Base Realignment and Closing Commission: Difficult Choices, Electoral Considerations, and the Future of National Leadership in a Partisan Age." In The Presidential Leadership Dilemma, eds. Julia R. Azari, Lara M. Brown, and Zim G. Nworka. Albany, NY: State University of New York Press.

Hassell, Hans J.G. and Samuel Kernell. 2015. "Veto Rhetoric and Legislative Riders." American Journal of Political Science 60(4): 845-859.

Helmke, Gretchen and Steven Levitsky. 2004. "Informal Institutions and Comparative Politics: A Research Agenda." 2(4): 725-740.

Jones, Charles O. 1994. The Presidency In A Separated System. Washington, DC: The Brookings Institution.

Kelley, Christopher S. and Bryan W. Marshall. 2009. "Assessing Presidential Power: Signing Statements and Veto Threats as Coordinated Strategies." American Politics Research 37(3): 508-533.

Kernell, Samuel. 2007: Going Public: New Strategies of Presidential Leadership. Washington, DC: CQ Press.

Kriner, Douglas L. and Eric Schickler. 2016. Investigating the President: Congressional Checks on Presidential Power. Princeton, NJ: Princeton University Press.

Lewallen, Jonathan. 2017. "The Issue Politics of Presidential Veto Threats." Presidential Studies Quarterly 47(2): 277-292. 
McCarty, Nolan M. and Keith T. Poole. 1995. "Veto Power and Legislation: An Empirical Analysis of Executive and Legislative Bargaining." Journal of Law, Economics, \& Organization 11(2): 282-312.

Moyers, Bill. 2005. Moyers on America. New York, NY: Anchor Books.

Neustadt, Richard E. 1991. Presidential Power and the Modern Presidents. New York, NY: Simon and Schuster, Inc.

Rozell, Mark J. 2010. Executive Privilege. Lawrence, KS: University Press of Kansas.

Skowronek, Stephen. 2011. Presidential Leadership in Political Time. Kansas, MO: University of Kansas Press. 